\title{
EFFECT OF COMPOST, COMPOST TEA AND BIO- FERTILIZER APPLICATION ON SOME CHEMICAL SOIL PROPERTIES AND RICE PRODUCTIVITY UNDER SALINE SOIL CONDITION.
}

Nasef, M. A.; Kh. A. Shaban and Amal F. Abd El-Hamid

Soils, Water and Environ. Res. Inst., Agric. Res. Center, Giza, Egypt

\begin{abstract}
Two field experiments were conducted at El-Rowad village, Sahl- El-Hossinia , El-Sharkia Governorate, Egypt, during summer2007 and 2008 seasons to study the effect of bio-fertilizer, compost and compost tea or in combination with nitrogen levels $(25,50$ and $100 \mathrm{~kg} \mathrm{~N} / \mathrm{fed}$ ). The compost is prepared from (rice straw, Maize and faba bean); Compost tea is prepared as a water extract of plant soluble nutrients, while the bio-fertilizer was a strain of Azospirillum braselence NO 40 (salt tolerant PGPR strain). The compost was applied before rice planting, and bio-fertilizer was applied seed coating while compost tea was sprayed after 25- 50- and 75days from rice planting.

The obtained results could be summarized as follows:

Application of compost, compost tea and bio-fertilizer combined with different levels of nitrogen mineral fertilizer led to increase significantly yield, weight of straw or grain (g) /plant, weight of $1000=$ grains $(\mathrm{g})$ and yield index. The macronutrients N, P and $\mathrm{K}$ contents in rice straw and grains increased significantly with the application of compost, compost tea and bio-fertilizer in combination with different levels of $\mathrm{N}$ mineral fertilizer, especially with the high levels as compared with $\mathrm{N}$ - mineral fertilizer levels applied alone. The combination of compost and /or compost tea and biofertilizer in addition to $\mathrm{N}$ - mineral levels enhanced the micronutrients ( $\mathrm{Fe}, \mathrm{Mn}$, and $\mathrm{Zn}$ and $\mathrm{Cu} \mathrm{mg} / \mathrm{kg}$ ) concentrations in rice straw and grains in both seasons. The effect of bio-fertilizer and other organic materials were due to lowering soil $\mathrm{pH}$. Meanwhile, EC of the studied saline soil decreased due to the leaching of salts as a result of improving soil physical conditions. The amount of all soil available nutrients $N, P$ and $\mathrm{K}$ (mg/kg soil) increased in the soil. Therefore Available Micronutrients $\mathrm{Fe}, \mathrm{Mn}, \mathrm{Zn}$ and $\mathrm{Cu}(\mathrm{mg} / \mathrm{kg}$ soil) also increased when compost, compost tea and bio-fertilizer were combined with different mineral $\mathrm{N}$ - fertilizer levels.
\end{abstract}

Keywords: compost-compost tea- bio-fertilizer - saline soil- rice crop.

\section{INTRODUCTION}

Egypt has a total area of about one million square kilometer. Egypt is situated in the arid and semi arid zones belt characterized by limited arable land resources, whether irrigated, alluvial agricultural land, natural grazing meadows or wetlands. Currently irrigated and cultivated land in Egypt is about 7.95 million feddans, from which 5.3 million feddans are fertile sedimentary lands in the Delta and the Valley, while the remaining land is desert, reclaimed during the last five decades. Egypt's population has reached 67.5 million, while the total area cultivated is 7.95 million feddans. According to the latest Central Authority for Public Mobilization and Statistics (CAPMAS) (2002). According to FAO (2004), Egypt is the largest rice producer in the Near East region. Rice (genus Oryza) is tolerant to desert, hot, humid, flooded, dry and cool conditions, and grows in saline, alkaline and 
acidic soils. .Most of the planted rice varieties are japonica. High solar radiation, the long days and the cool nights between May and September are favorable to a high rice yield. In fact, the Egyptian rice yield is one of the highest in the world (9.1 tones per hectare in 2001). Because of limited water resources, the government of Egypt has tried to limit rice cultivation, but cultivation has continued to expand due to rice high profits, and Egypt is today a major rice exporter.

Compost is a method utilized for the reduction, recycling, and re-utilization of crop residues (Bernal et al.., 1998). Epstein (1997) stated that the application of compost to soil favorably affects water holding capacity, erosion control, cation exchange capacity, $\mathrm{pH}$, macro elements availability, and soil structure, porosity and aeration. Large quantities of compost applied during several years are needed to observe changes in soil characteristics. Rebeka (2006) reported that most chemical parameters of the compost extracts generally reflect the chemical composition of the starting materials. In facts, compost fertilizer extracts show in average a lower $\mathrm{pH}$, lower salinity (ECe, for lower dilutions), and $\mathrm{K}$ concentration but a relatively higher $\mathrm{N}, \mathrm{P}, \mathrm{Ca}$ and $\mathrm{Mg}$ concentrations were for compost as a source of nutrients for plant growth. Evaluating the quantities of nutrients in the compost may help determine if this product meets the requirements of agronomic crops. In general, and because of the decomposition that organic wastes undergo in the composting process, there is a limited quantity of macro and micronutrients in the compost. Claudio et al.. (2007) found that the $\mathrm{pH}$ increment depends on the soil and the compost characters as well as on the dose and time of application. Increasing the period between compost application and the plantation to 30 days resulted in low soil pH values. Aly et al.. (1999) found highly significant increases in growth, grain yield and yield components of wheat due to the inoculation of crop seeds with symbiotic $\mathrm{N}_{2}$ Fixing bacteria. Hussein and Radwan (2001) reported that increasing N fertilizer rates led to significant increases in $\mathrm{N}$ and $\mathrm{P}$ contents in grains. Soh (2001) found that urea is preferable to nitrate for growing rice in flooded soils, and thus the Far East and the Middle-East are major consumers of urea. ElSheref et al.. (2004) found that grain yield and nitrogen content of rice crop increased significantly with increasing nitrogen dose. Tiwari et al.. (2000) recorded a significant increase in grain yield of rice at different applied levels of $\mathrm{N}$-fertilizer.

Compost tea can improve soil quality by increasing the number of beneficial soil organisms. Plants depend on soil microorganisms for gathering and incorporating nutrients in their roots. Compost tea contains substantial quantities of them, which are released into the soil when the compost tea is added around plants. Compost tea, in modern terminology, is a compost extract brewed with a microbial food source like: molasses, kelp, rock dust, humic - fulvic acids. The compost-tea brewing technique, (an aerobic process usually under forced aeration) extracts and grows population of microbial community (Mukhtar et al.., 2004). Lobna et al.. (2006) showed that the compost tea is a watery extract of plant soluble nutrients and microorganisms from compost. The organisms include bacteria, fungi, protozoa and nematodes. When applied to plant surfaces and drench into the rooting zone, 
it can protect the plant from diseases and enhance its growth. Crops can directly benefit from the macro-and micronutrients found in compost tea. Foliar fertilization with compost tea allows nutrients to be absorbed by the plants directly through stomata on their leaf surfaces. Compost tea can also provide nutrients to the soil through soil drenches.

The present study aims to study the effect of compost, compost tea and bio-fertilizer and/ or their combination with different nitrogen levels on some soil chemical properties, growth, yield and its components and grain protein content of rice (cv. Giza 187) grown on newly reclaimed saline soils as well as, to investigate if the use of these treatments would help to reduce the applied mineral nitrogen fertilizer rates and improve soil properties.

\section{MATERIALS AND METHODS}

A field experiments was carried out during two successive summer seasons of 2007 and 2008 at Sahl El-Hossinia village El-Rowad, El- Sharkia Governorate. The main target of this experiment is to evaluate the use of compost (residual straw of rice, corn and faba bean), compost tea and biofertilizer by soaking and /or foliar spraying (applied either each alone or in combination with different $\mathrm{N}$ - levels) on some chemical soil properties and growth, yield and yield components of rice cultivar Giza 187. Some chemical and physical analyses of the experimental soil are shown in Table (1). Statistically, the split plot design with three replications was used. The main plot was assigned to the fertilizer type and sub main plot was for the nitrogen levels (25, 50 and $100 \mathrm{~kg} \mathrm{~N} / \mathrm{fed})$.

Table (1): Some physical and chemical properties of the experimental soil

\begin{tabular}{|c|c|c|c|c|c|c|c|c|c|}
\hline Location & $\begin{array}{c}\text { Course } \\
\text { sand } \\
(\%)\end{array}$ & $\begin{array}{c}\text { Fine } \\
\text { sand } \\
(\%)\end{array}$ & $\begin{array}{l}\text { Silt } \\
(\%)\end{array}$ & $\begin{array}{l}\text { Clay } \\
(\%)\end{array}$ & \multicolumn{2}{|c|}{$\begin{array}{c}\text { Soil } \\
\text { Texture }\end{array}$} & \multicolumn{2}{|c|}{$\begin{array}{l}\text { OM } \\
(\%)\end{array}$} & $\begin{array}{c}\mathrm{CaCO}_{3} \\
(\%)\end{array}$ \\
\hline \multirow{7}{*}{$\begin{array}{c}\text { El-Rowad } \\
\text { village }\end{array}$} & 3.46 & 50.37 & 10.95 & 35.22 & San & dy clay & 0.5 & & 12 \\
\hline & $\mathrm{pH}$ & $E^{*}$ & \multicolumn{4}{|c|}{ Cations (meq/l) } & \multicolumn{3}{|c|}{ Anions (meq/l) } \\
\hline & $(1: 2.5)$ & $\left(\mathrm{dSm} \mathrm{m}^{-1}\right)$ & $\mathrm{Ca}^{++}$ & \begin{tabular}{l|l}
$\mathbf{M g}^{++}$ & \\
\end{tabular} & $\mathrm{Na}^{+}$ & $\mathrm{K}^{+}$ & $\mathrm{HCO}_{3}^{-}$ & $\mathrm{Cl}^{-}$ & $\mathrm{SO}_{4}^{-2}$ \\
\hline & 8.33 & 17.59 & 9.70 & 15.38 & 150 & 0.83 & 9.27 & 122 & 44.64 \\
\hline & \multicolumn{3}{|c|}{$\begin{array}{c}\text { Available } \\
\text { Macronutrients }(\mathrm{mg} / \mathrm{kg})\end{array}$} & \multicolumn{6}{|c|}{$\begin{array}{c}\text { Available } \\
\text { Micronutrients (mg/kg) }\end{array}$} \\
\hline & $\mathbf{N}$ & $\mathbf{P}$ & $\mathbf{K}$ & $\mathrm{Fe}$ & Mn & $\mathbf{Z n}$ & \multicolumn{3}{|c|}{$\mathbf{C u}$} \\
\hline & 38 & 5.61 & 183 & 2.48 & 3.98 & 0.72 & \multicolumn{3}{|c|}{0.081} \\
\hline
\end{tabular}

* EC. Estimated in soil paste

The obtained data were statistically analyzed as described by Gomez and Gomez (1984). Azospeirillum braselence NO. 40 (salt tolerant PGPR strain) was provided by the biofertilizer unit, Soil Microbiology, Soils, Water and Environ. Res. Inst. Agric. Res. Center Giza, Egypt was applied as bio-fertilizer. Compost was plowed 25 days before rice trams planting at a rate of 10 ton fed ${ }^{-1}$. The preparation of compost was done by using two ton of straw crop residuals (straw rice, maize stover and faba bean straw), air dried made into $5-10$ layers, each about $50 \mathrm{~cm}$ thick. Farmyard manure at a 
rate of $300 \mathrm{~kg} /$ pile was added to enhance microorganism activity, and it was then soaked with a sufficient quantity of water. Every 21 days, the heap of crop residuals was turned over until it became well decomposed. Chemical composition of the used compost is shown in Table (2). Composted tea was prepared by soaking one $\mathrm{m}^{3}$ from the previous compost in $500 \mathrm{~L}$ water, for 48 hrs, then filtered and the leachate was then used as compost tea. The chemical analysis of compost tea is shown in Table (3). The compost and compost tea analyses were done according to the standard methods as described by Brunner and Wasmer (1978). Rice grains were coated with an inoculum of Azopirillum (bio-fertilizer) and then soaked in the solution of compost tea for 6 hrs before sowing. The obtained leachate (compost tea) was also used as a foliar spray for rice plants after 25, 50 and 75 days from rice sowing at the rate $100 \mathrm{~L} / \mathrm{fed}$. The inoculated grain plots were also to supplied with a culture suspension of Azopirillum through drilling into soil near rice plants three times after 25,50 and 75 days of sowing at the rate of $5 \mathrm{~L} / 100 \mathrm{~L} / \mathrm{fed}$ (Omar et al.., 2000). Urea (46 N \%) was the source of mineral nitrogen fertilizer, which was applied at the rates of $25-50$ and $100 \mathrm{~kg} \mathrm{~N} / \mathrm{fed}$ alone or combined with compost, compost tea and bio-fertilizer. Calcium super-phosphate $\left(15.5 \% \mathrm{P}_{2} \mathrm{O}_{5}\right)$ was added at the rate of $30 \mathrm{~kg} \mathrm{P} \mathrm{P}_{5} / \mathrm{fed}$ during soil preparation, while potassium sulfate $\left(48 \% \mathrm{~K}_{2} \mathrm{O}\right)$ at the rate of 100 $\mathrm{kg} \mathrm{K} \mathrm{K}_{2} \mathrm{O} / \mathrm{fed}$ was added in two equal split doses before sowing and after 35 days from sowing.

Rice grains (Oryza Sativa) Giza (178) were obtained from the Field Crop, Res. Inst., ARC. The experiment started on the $5^{\text {th }}$ of May 2007 for the first season in the $3^{\text {rd }}$. of May 2008 for the second season.

Soil analysis: The soil surface $(0-30 \mathrm{~cm})$ sample was collected, air - dried, passed through a $2 \mathrm{~mm}$ sieve and mixed thoroughly according to Piper (1950). Calcium carbonate was determined using a Calcimeter and calculated as $\mathrm{CaCO}_{3} \%$. Organic matter was measured as described by Jackson (1976). Total soluble salts were determined in the saturated soil paste according to Jackson (1976). The $\mathrm{pH}$ was measured using a $\mathrm{pH}$ meter in soil suspension (1:2.5) soil water (Richards, 1954). Soluble cations and anions were determined in soil paste extract according to Black (1965). Available nitrogen was measured according to the modified Kjeldahal method by Black (1965). Available phosphorous was extracted by $0.5 \mathrm{~N}$ sodium bicarbonate and determined calorimetrically according to Olsen s' method (Jackson, 1976). The available K was determined using the flame photometer according to Soltanpour and Schwab (1977). Available micronutrients were extracted using ammonium bicarbonate (DTPA) and determined using Inductively Coupued Plasma (ICP) Spectrometry model 400, as described by Soltanpour and Schwab (1977).

\section{Plant analysis:}

Rice was harvested and grains were separated. Straw and grains were air dried and recorded as yield in ton /fed. Plant samples of ten a random plants were collected from each plot one day before harvesting, divided into grains and straw, air dried and then oven dried at $70{ }^{\circ} \mathrm{C}$, weighted to obtain dry matter of grains and straw per plant. The plant part samples were ground, $0.5 \mathrm{~g}$ of each sample was digested using $\mathrm{H}_{2} \mathrm{SO}_{4}$ and $\mathrm{HClO}_{4}$ mixture 
according to the methods described by Black (1965). The plant content of $\mathrm{N}$, $\mathrm{P}, \mathrm{K}, \mathrm{Fe}, \mathrm{Mn}, \mathrm{Zn}$, and $\mathrm{Cu}$ were determined in plant digestion using the methods described by Jackson (1976), Cottenie et al.. (1982) and Page et al.. (1982).

Table (2): Chemical analysis of the applied compost

\begin{tabular}{|c|c|c|c|c|c|c|c|c|c|c|c|c|}
\hline \multirow{2}{*}{$\begin{array}{l}\text { Moisture } \\
\text { content \% } \\
\end{array}$} & \multirow{2}{*}{$\begin{array}{c}\text { EC } \\
\mathrm{dSm}^{-1}\end{array}$} & $\mathrm{pH}$ & C & $\mathbf{C} / \mathbf{N}$ & O.M & $\mathbf{N}$ & $\mathbf{P}$ & K & $\mathrm{Fe}$ & Mn & $\mathrm{Zn}$ & $\mathrm{Cu}$ \\
\hline & & \multicolumn{7}{|c|}{ (\%) } & \multicolumn{4}{|c|}{$\left(\mathrm{mgkg}^{-1}\right)$} \\
\hline $22-27$ & 3.35 & 7.4 & 27 & 9.1 & 33 & 2.87 & 0.83 & 1.37 & 225 & 97 & 130 & 44 \\
\hline
\end{tabular}

Table (3): Chemical analysis of the applied compost tea

\begin{tabular}{|c|c|c|c|c|c|c|c|c|c|c|}
\hline \multirow{2}{*}{$E C\left(d_{S m}^{-1}\right)$} & \multirow{2}{*}{ pH } & C & O.M & $\mathbf{N}$ & $\mathbf{P}$ & $\mathrm{K}$ & $\mathrm{Fe}$ & Mn & $\mathrm{Zn}$ & $\mathrm{Cu}$ \\
\hline & & \multicolumn{5}{|c|}{ (\%) } & \multicolumn{4}{|c|}{$\left(\mathbf{m g k g}^{-1}\right)$} \\
\hline 1.6 & 7.29 & 12 & 42 & 2.21 & 0.60 & 1.23 & 135 & 82 & 112 & 34 \\
\hline
\end{tabular}

\section{RESULTS AND DISCUSSION}

\section{Effect of bio- and organic fertilizers applied under different levels of} nitrogen on yield and yield components:

Direct effect of bio-fertilizer, compost and compost tea applied under different nitrogen levels during both tested seasons on rice yield are shown in Table (4). Results showed that the values of dry matter yields in both seasons increased with increasing $\mathrm{N}$ mineral rate in combination with biofertilizer, compost and compost tea. These increases in both rice straw and grain yields are noticed in all the studied experimental plots. It was observed in Table (4) that the weight (ton /fed) of rice plant was significantly increased due to the use of the tested treatments in combination with different $\mathrm{N}$-levels. In this regard, the response to compost was more pronounced as compared to other amendments when applied with chemical fertilizer. The yield of rice straw and grains tended to increase due to the use of different amendments, since it was 2.096 ton /fed for the mineral N- rates of $100 \mathrm{~kg} \mathrm{~N}, 4.851$ ton /fed for bio-fertilizer combined with $50 \mathrm{~kg} \mathrm{~N} / \mathrm{fed}, 4.947 \mathrm{ton} / \mathrm{fed}$ for compost combined with $100 \mathrm{~kg} \mathrm{~N} /$ fed and $4.685 \mathrm{ton} /$ fed for compost tea combined with $50 \mathrm{~kg} \mathrm{~N} / \mathrm{fed}$ for straw. While, for grains, the corresponding increase was 1.973 for the mineral $\mathrm{N}$ - rates of $50 \mathrm{~kg} \mathrm{~N} / \mathrm{fed} ; 4.026$ for bio-fertilizer combined with $50 \mathrm{~kg} \mathrm{~N} / \mathrm{fed} ; 4.366$ ton/fed for compost combination with $100 \mathrm{~kg} \mathrm{~N} / \mathrm{fed}$ and 4.261 ton/fed for compost tea combined with $50 \mathrm{~kg} \mathrm{~N} / \mathrm{fed}$ in the first season, while the highest values in the second season were 2.159, 4.851 4.998 and 4.752 Ton /fed for straw and 1.985, $4.149,4.372$ and 4.266 ton/fed for grains due to $100 \mathrm{~kg} \mathrm{~N} / \mathrm{fed}$, bio-fertilizer combined with $50 \mathrm{~kg} \mathrm{~N}$ /fed, Compost and compost tea both combined with $100 \mathrm{~kg} \mathrm{~N} / \mathrm{fed}$, respectively. Application of amendments combination with any level of mineral $\mathrm{N}$ - mineral fertilizer increased significantly grains/plant (g), 1000grain (g) and grain yield index (\%) in both seasons compared to the treatments received $\mathrm{N}$ - mineral fertilizer alone in both seasons. These findings are in harmony with those reported by Tiwari et al. (2001) and Shaban et al. (2008). 
Nasef, M. A. et al.

4

2614 
It is worthy to mention that the superiority of crop yields under the studied treatments was in the following order: compost > Bio-Fertilizer > compost tea $>\mathrm{N}$-mineral fertilizer and this was mainly due to the low EC $\mathrm{Cw}_{\mathrm{w}}$, which positively affected soil salinity and sodicity during the studied throughout crop cultivation.

\section{$\mathrm{N}, \mathrm{P}$ and $\mathrm{K}$ concentrations in rice (straw and grains):}

Data of N, P and K concentrations in both straw and grains of rice as affected by the studied bio- and organic fertilizers are presented in Table (5) Results of N, P and $\mathrm{K}$ concentrations in straw and grain of rice showed pronounced decreases with increasing soil salinity. The sufficient concentrations of $\mathrm{N}, \mathrm{P}$ and $\mathrm{K}$ ranged $2.07-2.45 ; 0.21-0.50$ and $1.51-3.0 \%$ for N, P and K, respectively as mentioned by Benton et al.. (1992). Low values of $\mathrm{N}, \mathrm{P}$ and $\mathrm{K}$ contents were observed at mineral $-\mathrm{N}<$ bio-fertilizer $<$ compost > compost tea combined with $25 \mathrm{~kg} \mathrm{~N} / \mathrm{fed}$. While the highest contents of $\mathrm{N}$ were $2.36 \%$ for straw and $1.82 \%$ for grain, $2.41 \%$ for straw and $2.13 \%$ for grains and $2.37 \%$ for straw and $2.09 \%$ for grains for $P$ contents ; $0.35 \%$ for straw and $0.45 \%$ for grains ; 0.38 for straw and $0.49 \%$ for grain and $0.36 \%$ for straw and $0.47 \%$ for grain and for $\mathrm{K}$ contents 2.03 $\%$ for straw and $1.55 \%$ for grain $; 2.12 \%$ for straw and $1.60 \%$ for grain and 2.07 for straw and $1.59 \%$ for grain of $\mathrm{K}$ for Bio-fertilizer combined with $50 \mathrm{~kg}$ $\mathrm{N} / \mathrm{fed}$; compost or compost tea combined with $100 \mathrm{~kg} \mathrm{~N} / \mathrm{fed}$ respectively . These results are in agreement with those obtained by Hussein and Radwan (2001). Generally, the obtained increases in macronutrient concentration in straw and grains may be due to the decrease of soil pH, soil salinity, and the increased activity of microorganisms in soil. Foliar fertilization with compost tea allows nutrients to be absorbed by the plants directly through stomata on their leaf surfaces. Compost tea can also provide nutrients to the soil through soil drenches. These results agreed with those obtained by Lobna et al.. (2006).

Data in Table (5) showed a significant increase effect on grain protein content due to the combination of $\mathrm{N}$ - fertilizer with bio- fertilizer, compost and compost tea. It was responded to increasing nitrogen levels up to $100 \mathrm{~kg}$ $\mathrm{N} / \mathrm{fed}$ in both seasons, . This effect might be due to the increasing of available nitrogen for plant metabolism. Similar results were reported by Abou-Khalifa (1996), Badawi (2002) and Salem (2006). Finally, the use of bio-fertilizer combined with $50 \mathrm{~kg} \mathrm{~N}$, and compost or compost tea in combination with $100 \mathrm{~kg} \mathrm{~N}$ recorded the highest N, P and K contents of both straw and grains in favor of compost treatment.

Micronutrients concentrations in rice straw and grains:

Effects of bio and organic fertilizer application under different mineral $\mathrm{N}$ - fertilizer levels on the concentration of some micronutrients ( $\mathrm{Fe}, \mathrm{Mn}, \mathrm{Zn}$ and $\mathrm{Cu}$ ), in both straw and grains of rice plants are presented in Tables (5). Data showed that applying the amendments caused markedly increases in the concentrations of $\mathrm{Fe}, \mathrm{Mn}, \mathrm{Zn}$, and $\mathrm{Cu}$ in rice plants, with a more pronounced increase with increasing the level of $\mathrm{N}$ - mineral fertilizer. 
Nasef, M. A. et al.

5

2616 
The highest contents of $\mathrm{Fe}, \mathrm{Mn}, \mathrm{Zn}$, and $\mathrm{Cu}$ in rice straw were 98.06, 70.12, 46.58 , and $6.29 \mathrm{mg} / \mathrm{kg}$ against $62.35,27.66,22.26$, and $2.41 \mathrm{mg} / \mathrm{kg}$ for grains, respectively, for compost combined with $100 \mathrm{~kg} \mathrm{~N} / \mathrm{fed}$ compared with all other treatments. These results are in harmony with those obtained by Shaban and Helmy (2006) and Lobna et al.. (2006). The relative increases of the studied micronutrients $(\mathrm{Fe}, \mathrm{Mn}, \mathrm{Zn}$ and $\mathrm{Cu}$ ) in rice crop (straw and grains) are mainly depending on the used bio and organic fertilizers which, could be arranged as follows:

Compost $>$ bio-fertilizer $>$ compost tea $>$ mineral $\mathrm{N}$ - fertilizer for $\mathrm{Fe}$ in straw and grins. Compost $>$ compost Tea $>$ Bio-fertilizer $>$ mineral $\mathrm{N}$-fertilizer for $\mathrm{Mn}, \mathrm{Zn}$ and $\mathrm{Cu}$ in straw and grains, respectively. All this micronutrients concentration in straw and grains were in sufficient critical limit according to Benton et al. (1992).

\section{Some chemical soil properties as affected by bio and organic fertilizers: Soil reaction $(\mathrm{pH})$ :}

Throughout this work, the chemical fertilizer and bio-fertilizer, compost and compost tea contributed to the decrease of soil $\mathrm{pH}$.

Table (6) postulated that the use of different $\mathrm{N}$ - fertilizer levels, generally, exhibited the highest soil $\mathrm{pH}$ values. It was also found that soil $\mathrm{pH}$ tends to decrease slightly due to the application of compost, compost tea and bio-fertilizer. The soils of all experimental plot were characterized by slight to moderate alkaline conditions, where the $\mathrm{pH}$ value is always around $8.28-$ 7.94. These findings are in agreement with those reported by Wahdan et al.. (1999). . Data present in Table (6) showed also that soil pH tends to decrease slightly throughout the two seasons with increasing the $\mathrm{N}$ - mineral fertilizer level combined with bio-fertilizer, compost or compost tea; hence values of $\mathrm{pH}$ soil were ranged between 8.00 to 8.22 in the first season and 7.94 to 8.15 in second seasons. The lowest value of $\mathrm{pH} 7.94$ was obtained in the soil treated with compost combined with $100 \mathrm{~kg} \mathrm{~N} / \mathrm{fed}$. These findings are in agreement with those reported by Rebeka (2006). The application of compost, compost tea and bio-fertilizer in general reduced the soil $\mathrm{pH}$. The $\mathrm{pH}$ of saline sodic soil was reduced from $(8.28-8.00)$ to $(8.15-7.94)$ due to the application of bio and organic fertilizers treatments after rice harvesting in both seasons.

\section{Soil salinity (EC) as affected by different fertilizer sources:}

Soil salinity after rice harvest as affected by different fertilizer sources is given in Tables (6). Results showed that the studied soils are generally characterized, by a saline nature the characters that prevailed in the semiarid regions. These characters include the accumulation of salts in surface zone of the soil, mainly due to high evaporation process under the dry and hot climate. Data in Table (6) revealed that the values of soil salinity ECe $(\mathrm{dS} / \mathrm{m})$ decreased significantly by increasing mineral nitrogen fertilizer levels combined with bio-fertilizer or compost and compost tea. Concerning the effect of mineral nitrogen fertilizer levels or bio-fertilization on soil salinity and salt distribution, the degrees of soil salinity were slightly affected. These results are in agreement with those obtained by Burr et al.. (1978). Application of bio and organic fertilizer combined with different nitrogen levels 
Nasef, M. A. et al.

led to a decrease in soil salinity because bio- fertilizer or compost and/or compost tea could improve the soil physical properties (increasing soil porosity).

Table (6): Soil reaction (pH), electric conductivity (EC) and $\mathrm{N}, \mathrm{P}$ and $\mathrm{K}$ contents in soil after rice harvesting as affected by bio, organic and nitrogen fertilizers during 2007 and 2008 seasons

\begin{tabular}{|c|c|c|c|c|c|c|}
\hline \multirow[t]{2}{*}{ Treatments } & \multirow{2}{*}{$\begin{array}{l}\text { N rate } \\
\text { kgfed }^{-1}\end{array}$} & \multirow{2}{*}{$\underset{(1: 2.5)}{\mathrm{pH}}$} & \multirow{2}{*}{$\begin{array}{c}E C \\
\left(\mathrm{dSm}^{-1}\right)\end{array}$} & \multicolumn{3}{|c|}{$\begin{array}{c}\text { Available macronutrients } \\
\left(\mathrm{mgkg}^{-1}\right)\end{array}$} \\
\hline & & & & $\mathbf{N}$ & $\mathbf{P}$ & K \\
\hline \multicolumn{7}{|c|}{ Season 2007} \\
\hline \multirow{3}{*}{ N- Mineral } & 25 & 8.28 & 13.69 & 46 & 5.86 & 197 \\
\hline & 50 & 8.21 & 12.96 & 64 & 5.90 & 214 \\
\hline & 100 & 8.18 & 12.73 & 69 & 6.03 & 221 \\
\hline \multicolumn{2}{|l|}{ Mean } & & 13.12 & 59 & 5.93 & 211 \\
\hline \multirow{3}{*}{ Bacteria (NO40) } & 25 & 8.20 & 12.66 & 60 & 5.94 & 208 \\
\hline & 50 & 8.12 & 11.28 & 77 & 6.12 & 217 \\
\hline & 100 & 8.01 & 10.82 & 82 & 6.54 & 234 \\
\hline \multicolumn{2}{|l|}{ Mean } & & 11.59 & 73 & 6.20 & 219 \\
\hline \multirow{3}{*}{ Compost } & 25 & 8.22 & 12.84 & 58 & 5.98 & 210 \\
\hline & 50 & 8.14 & 11.75 & 73 & 6.24 & 219 \\
\hline & 100 & 8.07 & 10.99 & 79 & 6.88 & 238 \\
\hline \multicolumn{2}{|l|}{ Mean } & & 11.86 & 70 & 6.37 & 222 \\
\hline \multirow{3}{*}{ Compost (tea) } & 25 & 8.18 & 12.14 & 68 & 6.02 & 211 \\
\hline & 50 & 8.06 & 11.05 & 83 & 6.34 & 221 \\
\hline & 100 & 8.00 & 10.33 & 86 & 6.81 & 240 \\
\hline \multicolumn{2}{|l|}{ Mean } & & 11.17 & 79 & 6.39 & 224 \\
\hline \multicolumn{7}{|c|}{ Season 2008} \\
\hline \multirow{3}{*}{ N- Mineral } & 25 & 8.15 & 10.22 & 56 & 6.13 & 208 \\
\hline & 50 & 8.13 & 10.46 & 78 & 6.38 & 221 \\
\hline & 100 & 8.10 & 10.29 & 82 & 6.57 & 229 \\
\hline \multicolumn{2}{|l|}{ Mean } & & 10.32 & 72 & 6.36 & 219 \\
\hline \multirow{3}{*}{ Bacteria (NO40) } & 25 & 8.08 & 10.19 & 62 & 6.23 & 215 \\
\hline & 50 & 8.07 & 9.96 & 85 & 6.58 & 224 \\
\hline & 100 & 7.97 & 9.91 & 92 & 6.69 & 238 \\
\hline \multicolumn{2}{|l|}{ Mean } & & 10.02 & 80 & 6.50 & 225 \\
\hline \multirow{3}{*}{ Compost } & 25 & 8.04 & 10.05 & 64 & 6.49 & 220 \\
\hline & 50 & 8.01 & 9.81 & 93 & 6.88 & 230 \\
\hline & 100 & 7.94 & 9.74 & 96 & 6.94 & 244 \\
\hline \multicolumn{2}{|l|}{ Mean } & & 9.87 & 84 & 6.77 & 231 \\
\hline \multirow{3}{*}{ Compost (tea) } & 25 & 8.06 & 10.04 & 65 & 6.45 & 218 \\
\hline & 50 & 8.00 & 9.59 & 90 & 6.87 & 227 \\
\hline & 100 & 7.98 & 9.76 & 94 & 6.91 & 243 \\
\hline \multicolumn{2}{|l|}{ Mean } & & 9.79 & 83 & 6.74 & 229 \\
\hline \multicolumn{2}{|l|}{ LSD \%5 fertilizer } & 1.07 & 0.087 & 3.12 & 0.36 & 7.01 \\
\hline \multicolumn{2}{|l|}{ LSD \% N Rate } & ns & 0.068 & 3.24 & 0.35 & 6.82 \\
\hline \multicolumn{2}{|l|}{ LSD \% 5 season } & ns & 0.173 & 0.21 & 0.20 & 10.04 \\
\hline
\end{tabular}


These findings are in agreement with those reported by Tandon (2000) who found that physical properties (hydraulic conductivity, bulk density and total porosity) of salt affected soil greatly improved when compost is applied. The decomposition of compost and compost tea and bio-fertilizer releases acids forming compounds and active microorganisms, which react with the soluble salts already present in soil either to convert them into soluble salts or at least increase their solubility .

Available macronutrient contents in the soil:

Nitrogen, Phosphorus and Potassium are the major elements for plant growth. Data in Table (6) showed the amounts of some available macronutrients, $\mathrm{N}, \mathrm{P}$ and $\mathrm{K}$ ( $\mathrm{mg} / \mathrm{kg}$ soil) in the studied soil as affected by bio, organic and $\mathrm{N}$ fertilizers during both seasons. In fact the compost and compost tea combined with high rate of nitrogen fertilizer are rich in organic materials as well as N, P and K. Results also, indicated that available N, P and $\mathrm{K}$ ranged from 46 to $86 \mathrm{mg} / \mathrm{kg}$ soil in first season and from 56 to 96 $\mathrm{mg} / \mathrm{kg}$ soil in second season for N, from 5.86 to $6.88 \mathrm{mg} / \mathrm{kg}$ in first season and from 6.13 to $6.94 \mathrm{mg} / \mathrm{kg}$ in second season for $\mathrm{P}$ and from 197 to 240 $\mathrm{mg} / \mathrm{kg}$ in the first season and from 208 to $244 \mathrm{mg} / \mathrm{kg}$ in the second season for $\mathrm{K}$. The highest values of $96,6.94$ and $244 \mathrm{mg} / \mathrm{kg}$ soil for $\mathrm{N}, \mathrm{P}$ and $\mathrm{K}$, respectively, were obtained in soil treated with compost combined with high level of mineral $\mathrm{N}$ - fertilizer compared to other treatments. Values of available $\mathrm{N}, \mathrm{P}$ and $\mathrm{K}$ increased significantly with addition of compost and compost tea combined with high level of $\mathrm{N}$-mineral fertilizer but the $\mathrm{N}, \mathrm{P}$ and $\mathrm{K}$ increased with bio-fertilizer combined and with $50 \% \mathrm{~N}$ mineral fertilizer. The decomposition of applied compost, compost tea and bio-fertilizer resulted in reduction of soil $\mathrm{pH}$ as various acids (amino acids, such as glycine and cystein as well as humic acid) or acid forming compounds and active microorganisms were released from the addition of organic materials and biofertilizer. These findings are in agreement with those reported by (Brady and Weil, 2005). This reduction in soil pH increased the availability of nutrients in alkaline soil that become available to the plants.

Micronutrients content in soil as affected by bio, organic and mineral nitrogen fertilizers:

Data in Table (7) bio-organic and mineral nitrogen that pronounced increases in soil available microelement contents ( $\mathrm{Fe}, \mathrm{Mn}, \mathrm{Zn}$ and $\mathrm{Cu}$ ) were achieved as a result of the application of compost or compost tea and biofertilizer combined with $\mathrm{N}$ - mineral fertilizer levels during both seasons under rice cropping. This is more related to the residual of organic compounds that are directly decomposed after different biochemical and chemical changes, which led to the release of more available microelements. These findings are in agreement with those obtained by Shaban and Helmy (2006). The highest values were 2.93 and $3.36 \mathrm{mg} / \mathrm{kg}$ for Fe; 5.28 and $5.37 \mathrm{mg} / \mathrm{kg}$ for $\mathrm{Mn}, 1.09$ and $1.26 \mathrm{mg} / \mathrm{kg}$ for $\mathrm{Zn}$ and 0.19 and $0.25 \mathrm{mg} / \mathrm{kg}$ for $\mathrm{Cu}$ soil during the first season and second season, respectively. It is worthy to mention that the contents of all the studied available microelements, in general, lay within the sufficient limits of $\mathrm{Fe}$ and $\mathrm{Mn}$ or in the critical limits identical division for the others (FAO, 1992). 
Nasef, M. A. et al.

Table (7): Available micronutrient contents in the soil after rice harvesting as affected by bio, organic and nitrogen fertilizers during 2007 and 2008 seasons

\begin{tabular}{|c|c|c|c|c|c|}
\hline \multirow{2}{*}{ Treatments } & \multirow{2}{*}{$\mathbf{N} /$ unit } & \multicolumn{2}{|c|}{ Macronutrients } & \multicolumn{2}{|c|}{$\left(\mathrm{mgkg}^{-1}\right)$} \\
\hline & & $\mathrm{Fe}$ & Mn & Zn & $\mathrm{Cu}$ \\
\hline \multicolumn{6}{|c|}{ Season 2007} \\
\hline \multirow{3}{*}{ N- Mineral } & 25 & 2.53 & 4.04 & 0.85 & 0.10 \\
\hline & 50 & 2.79 & 4.15 & 0.88 & 0.14 \\
\hline & 100 & 2.81 & 4.32 & 0.93 & 0.16 \\
\hline \multicolumn{2}{|l|}{ Mean } & 2.71 & 4.17 & 0.89 & 0.13 \\
\hline \multirow{3}{*}{ Bacteria (NO40) } & 25 & 2.60 & 4.13 & 0.89 & 0.12 \\
\hline & 50 & 2.88 & 4.59 & 1.02 & 0.15 \\
\hline & 100 & 2.90 & 4.78 & 1.06 & 0.18 \\
\hline \multicolumn{2}{|l|}{ Mean } & 2.79 & 4.50 & 0.99 & 0.15 \\
\hline \multirow{3}{*}{ Compost } & 25 & 2.64 & 5.02 & 1.01 & 0.14 \\
\hline & 50 & 2.89 & 5.21 & 1.06 & 0.19 \\
\hline & 100 & 2.93 & 5.28 & 1.09 & 0.18 \\
\hline \multicolumn{2}{|l|}{ Mean } & 2.82 & 5.17 & 1.05 & 0.17 \\
\hline \multirow{3}{*}{ Compost tea } & 25 & 2.62 & 4.87 & 0.99 & 0.13 \\
\hline & 50 & 2.85 & 4.96 & 1.05 & 0.15 \\
\hline & 100 & 2.88 & 4.99 & 1.07 & 0.17 \\
\hline \multicolumn{2}{|l|}{ Mean } & 2.78 & 4.94 & 1.03 & 0.15 \\
\hline \multicolumn{6}{|c|}{ Season 2008} \\
\hline \multirow{3}{*}{ N- Mineral } & 25 & 2.69 & 4.35 & 1.02 & 0.12 \\
\hline & 50 & 2.80 & 4.39 & 1.09 & 0.16 \\
\hline & 100 & 2.84 & 4.42 & 1.13 & 0.18 \\
\hline \multicolumn{2}{|l|}{ Mean } & 2.77 & 4.38 & 1.08 & 0.15 \\
\hline \multirow{3}{*}{ Bacteria (NO40) } & 25 & 2.63 & 4.44 & 1.11 & 0.14 \\
\hline & 50 & 2.94 & 4.63 & 1.18 & 0.20 \\
\hline & 100 & 2.91 & 4.80 & 1.22 & 0.22 \\
\hline \multicolumn{2}{|l|}{ Mean } & 2.82 & 4.62 & 1.17 & 0.18 \\
\hline \multirow{3}{*}{ Compost } & 25 & 3.17 & 5.25 & 1.15 & 0.16 \\
\hline & 50 & 3.33 & 5.32 & 1.19 & 0.23 \\
\hline & 100 & 3.36 & 5.37 & 1.26 & 0.25 \\
\hline \multicolumn{2}{|l|}{ Mean } & 3.29 & 5.31 & 1.20 & 0.21 \\
\hline \multirow{3}{*}{ Compost (tea) } & 25 & 3.15 & 5.10 & 1.06 & 0.17 \\
\hline & 50 & 3.30 & 5.16 & 1.13 & 0.19 \\
\hline & 100 & 3.32 & 5.23 & 1.18 & 0.21 \\
\hline \multicolumn{2}{|l|}{ Mean } & 3.26 & 5.16 & 1.12 & 0.19 \\
\hline \multicolumn{2}{|l|}{ LSD \%5 fertilizer } & 1.12 & 0.079 & 0.14 & 0.0023 \\
\hline \multicolumn{2}{|l|}{ LSD \% N Rate } & ns & 0.078 & 0.44 & 0.0027 \\
\hline \multicolumn{2}{|l|}{ LSD \% 5 season } & 2.42 & 0.120 & 0.94 & 0.0144 \\
\hline
\end{tabular}




\section{REFERENCES}

Aly, S. S., S. M. Soliman, E. A. El-Akel and M. E. Aly (1999). significance of free N2-Fixing bacteria and nitrification inhibitors on saving the applied nitrogen to wheat plants. Bulletin Fac. Agric. Cairo Univ., 50: (347382).

Abou-Khalifa, A. A. B. (1996). Response of some rice varieties to nitrogen fertilizer application under different irrigation intervals. Ph.D. Thesis, Fac. Agric., Moshtohor, Zagazig University.

Badawi, S. A. E. (2002). Physiological studies on rice crop. M.Sc. Thesis, Fac. Agric., Kafr, El-Sheikh, Tanta Univ., Egypt.

Black, C. A. (Ed) (1965). Methods of Soil Analysis. Ser. Agron. No. 9 Amer. Soc. Agron., Madison, Wisconsin, USA.

Bernal, M. P., J. Cegara, A. Roig, M. A. Sánchez-Monedero, and C. Paredes (1998). Composting of organic wastes as a strategy for producing high quality organic fertilizers. $8^{\text {th }}$ International Conference on Management Strategies for Organic Waste Use in Agriculture. Rennes, France, 2629 May, 1998.

Benton , J. J., W. Benjamin and M. A. Harry (1992). " Macro-Micro elements." Publishing Inc. Plant analysis and Book. pp $129-131$.

Brady, N. C. and R. R. Weil (2005). The Nature and properties of soil (Thirteenth Edition). Macmillan Publishing Co. New York, USA.

Brunner, P. H. and H. R. Wasmer (1978). Methods of analysis of sewage sludge solid wastes and compost. W. H. O. International Reference Center for Wastes Disposal (H-8600), Dulendrof Switzerland.

Burr, T. J, M. N. Schroth, T. Suslow (1978). " Increased potato yields by treatment of seed pieces with specific strains of Pseudomonas fluorescens and Pseudomonas putida". Phytopathology. 68: 13771383.

Central Authority for Public Mobilization and Statistics (CAPMAS) (2002). Annual Book, Cairo.Egypt.

Cláudio P. J , C. N. Clésia, L. F. Renildes , R. C. Paulo and L. P. José (2007). Effects of composted urban solid waste addition on yield and metal contents of lettuce. J. Brazil. Chem. Soci., 18 (1):195- 204.

Cottenie, A., M. Verloo, G. Velghe and R. Cameriynck (1982). "Chemical Analysis of plant and soil." Laboratory of Analytical and Agrochemistry, State Univ., Ghent, Belgium.

El-Sheref, E. El.; M. Heam, A. Galeah and M. Abd El-Mameed (2004). Effect of nitrogen levels, hill spacing and rice cultivar mixtures on some rice characters. J. Agric. Sci. Monsoura Univ., 29: 535- 552.

Epstein, E. (1997). The Science of Composting. CRC Press LLC Boca Raton, Florida. , USA. 487 pp.

FAO (2004). Food and Agriculture Organization of the United Nation. International year of rice, 153, Rome, Italy.

FAO (1992). "Micronutrient and the nutrient status of soils." Soils Bull No: (48). Roma, Italy.

Gomez, K. A. and A. A. Gomez (1984). Statistical procedures for agricultural 
research. $2^{\text {nd }}$ ed. Pp.208-215.

Jackson, M. L. (1976). "Soil Chemical Analysis." Constable and Co. L.T. P., London, England.

Hussein, H. F. and S. M. Radwan (2001). Effect of bio-fertilization with different levels of nitrogen and phosphorus on wheat and associated weeds under weed control treatments. J. Biol. Sci., 4 (4): $435-441$

Lobna, A. Moussa ; Soheir, S. Fahmy and Abeer M. Shaltout (2006). Evaluation of some bacterial isolates and compost tea for biocontrolling Macrophomina phaseolina and Sclerotium rolfsii infected sunflower. Egypt. J. Agric. Res., 48 (5): 1331-1344.

Merrington, G., L. Winder, R. Parkinson, and M. Redman (2002). Agricultural pollution: environmental problems and practical solutions. 1 Ed Spon Press, UK.

Mukhtar, S., A. Kalbasi, and A. Ahmed. (2004). Composting. National Agricultural Biosecurity Center Consortium, USDA-APHIS Cooperative Agreement Project and Carcass Disposal Working Group.

Omar, M. N. A. ; A. T. Mostafa and A. S. Ahmed (2000). "Concentration vinasse as a novel diazotrophs growth medium (Biovinasse inoculate) and soil conditioner to improve faba bean yield under dripping irrigation systems ". Proceedings of the Tenth Conference of Microbiology, Egypt, No. 12 - 14 .pp 100-110.

Page, A. L.; R. H. Miller and D. R. Keeney (1982). "Methods of Chemical Analysis". Part 2: Chemical and microbiological properties (Second Edition). American Society of Agronomy, Inc. and Sci. Soc. of America, Inc. Publishers, Madison, Wisconsin, USA.

Piper, C. S. (1950). " Soil and Plant Analysis." Inter. Sci . Publishers. Inc., New York,USA.

Richards, L. A. (1954). Diagnosis and Improvement of Saline and Alkali Soils. U.S. Salinity Laboratory Staff. Agriculture Handbook, No.60.

Rebeka, S. L. (2006). Composting as an alternative method to dispose of slaughterhouse wastes in Puerto rice. MSc. Thesis Animal Industry. Universty of Puerto Rico. Mayaguez Campus.

Salem, A. K. M. (2006). Effect of nitrogen levels, plant spacing and time of farmyard manure application on the productivity of rice. J. Appl. Sci. Res., 2 (11): 980-987.

Shaban, Kh. A. and A. M. Helmy (2006). "Response of wheat to mineral and bio-fertilization under saline conditions ." Zagazig ,J. Agric. Res., 33 (6): 1189- 1205.

Shaban, Kh. A. H. , E. E. E. Khafaga and H. S. Saied (2008). Effects of organic manure and mineral $\mathrm{N}$ on soil properties and spinach (Spinacia olerasea L.) productivity under saline soil conditions. J. Agric. Sci. Mansoura Univ., 33(5): 3865- 3879.

Soh, K. G. (2001). Global supply and demand for urea. MITCO Marketing and Trading Forum 2001, Bangi, Malaysia, 27 August, 2001.

SoltanPour, N. and A. P. Schwab (1977). A new soil test for simultaneous extraction of macro and micronutrients in alkaline soils. Commun. Soil Sci. plant Anal., 3: 195. 
Soltanpour, N. (1985). Use of ammonium bicarbonate- DTPA soil test to evaluate element availability and toxicity . Soil Sci . Plant Anal., 16 (3): $323-338$.

Tandon , H. L . S. (2000). Fertilizer organic manures wastes and biofertilizers components of integrated plant. Fertilizer Development and consultation organization 204- 204, A Bhanot Corner, 1-2 Pamposh Enclave New Delhi. 110048. India.

Tiwari , V. N; Tiwari , K. N. and P. N. Awasthi (2000). Role of sesbania rastrata and phosphor-microbe at varying level of $\mathrm{N}$ - in sustaining the production and productivity of soil under rice - wheat / chickpea cropping sequence. J. Ind. Soci. Soil Sci., 48 (2): 257- 262.

Wahdan, A. A., S. A. El-Gendi and S. A. Abd El-Mawgoud (1999). Amelioration techniques for sodic soils in Al-Fayoum Oasis . Egypt. J. Soil Sci., 39 (2): 199- 210.

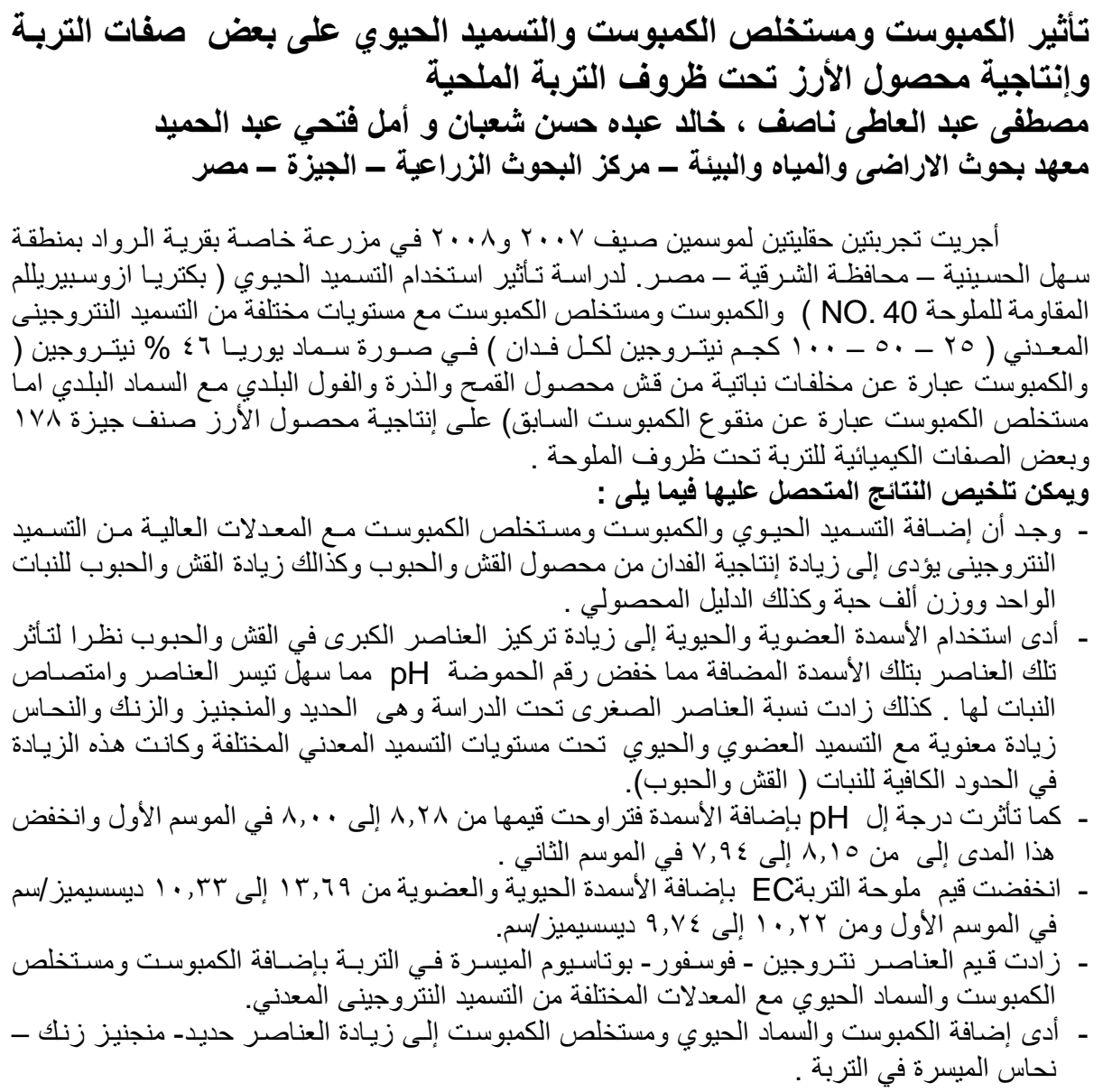


J. Agric. Sci. Mansoura Univ., 34 (4): 2609 - 2623, 2009

Table (4): Rice yield and its components as affected by bio-and organic fertilizer under mineral $\mathrm{N}$ fertilization during 2007 and 2008 seasons

\begin{tabular}{|c|c|c|c|c|c|c|c|c|c|c|c|c|c|}
\hline \multirow{3}{*}{ Treatment } & \multirow{3}{*}{$\mathrm{N} /$ unit } & \multicolumn{4}{|c|}{ Weight of plant (g) } & \multicolumn{4}{|c|}{ Weight of yield $\left(\right.$ ton fed $\left.{ }^{-1}\right)$} & \multirow{2}{*}{\multicolumn{2}{|c|}{$\begin{array}{c}\text { Weight } \\
(1000) \text { grains }(g)\end{array}$}} & \multirow{2}{*}{\multicolumn{2}{|c|}{$\begin{array}{c}\text { Yield index } \\
(\%)\end{array}$}} \\
\hline & & \multicolumn{2}{|c|}{ Straw } & \multicolumn{2}{|c|}{ Grains } & \multicolumn{2}{|c|}{ Straw } & \multicolumn{2}{|c|}{ Grains } & & & & \\
\hline & & 2007 & 2008 & 2007 & 2008 & 2007 & 2008 & 2007 & 2008 & 2007 & 2008 & 2007 & 2008 \\
\hline \multirow{3}{*}{ Mineral } & 25 & 2.52 & 2.66 & 1.25 & 1.29 & 0.124 & 0.139 & 0.059 & 0.064 & 20.58 & 19.96 & 32 & 31 \\
\hline & 50 & 2.84 & 2.88 & 1.28 & 1.32 & 2.096 & 2.159 & 1.973 & 1.985 & 24.63 & 24.66 & 48 & 48 \\
\hline & 100 & 2.93 & 2.95 & 1.35 & 1.36 & 3.178 & 3.457 & 2.998 & 3.156 & 26.39 & 26.45 & 48 & 47 \\
\hline \multicolumn{2}{|c|}{ Mean } & 2.76 & 2.83 & 1.41 & 1.32 & 1.800 & 1.918 & 1.676 & 1.735 & 23.87 & 23.69 & 43 & 42 \\
\hline \multirow{3}{*}{$\begin{array}{c}\text { Bacteria } \\
\text { (NO40) }\end{array}$} & 25 & 2.62 & 2.66 & 1.33 & 1.36 & 0.356 & 0.361 & 0.089 & 0.096 & 22.46 & 22.50 & 25 & 21 \\
\hline & 50 & 2.98 & 3.02 & 2.54 & 2.56 & 4.769 & 4.851 & 4.026 & 4.149 & 28.66 & 28.69 & 45 & 46 \\
\hline & 100 & 2.88 & 2.93 & 2.44 & 2.47 & 2.953 & 2.971 & 2.327 & 2.339 & 27.82 & 27.88 & 49 & 44 \\
\hline \multicolumn{2}{|c|}{ Mean } & 3.83 & 2.87 & 2.10 & 2.13 & 2.693 & 2.728 & 2.147 & 2.195 & 26.31 & 26.36 & 40 & 37 \\
\hline \multirow{3}{*}{ Compost } & 25 & 2.64 & 2.67 & 1.36 & 1.38 & 0.359 & 0.366 & 0.102 & 0.109 & 22.48 & 22.50 & 22 & 23 \\
\hline & 50 & 3.01 & 3.05 & 2.59 & 2.63 & 4.896 & 4.925 & 4.347 & 4.352 & 29.16 & 29.24 & 47 & 47 \\
\hline & 100 & 3.06 & 3.09 & 2.61 & 2.66 & 4.947 & 4.998 & 4.366 & 4.372 & 29.23 & 29.26 & 46 & 46 \\
\hline \multicolumn{2}{|c|}{ Mean } & 2.90 & 2.94 & 2.19 & 2.22 & 3.400 & 3.430 & 2.938 & 2.944 & 26.96 & 27.00 & 38 & 39 \\
\hline \multirow{3}{*}{$\begin{array}{l}\text { Compost } \\
\text { tea }\end{array}$} & 25 & 2.60 & 2.63 & 1.35 & 1.37 & 0.298 & 0.296 & 0.123 & 0.128 & 22.36 & 22.40 & 29 & 30 \\
\hline & 50 & 2.99 & 3.03 & 2.61 & 2.64 & 4.685 & 4.752 & 4.258 & 4.261 & 28.63 & 28.65 & 47 & 47 \\
\hline & 100 & 3.02 & 3.05 & 2.63 & 2.65 & 4.648 & 4.667 & 4.261 & 4.266 & 28.69 & 28.72 & 48 & 47 \\
\hline \multicolumn{2}{|c|}{ Mean } & 2.87 & 2.90 & 2.20 & 2.22 & 3.210 & 3.240 & 3.045 & 2.885 & 26.56 & 26.59 & 41 & 41 \\
\hline \multicolumn{2}{|c|}{ LSD \%5 fertilizer } & \multicolumn{2}{|c|}{0.76} & \multicolumn{2}{|c|}{0.081} & \multicolumn{2}{|c|}{0.34} & \multicolumn{2}{|c|}{0.37} & \multicolumn{2}{|c|}{ ns } & \multicolumn{2}{|c|}{1.44} \\
\hline \multicolumn{2}{|c|}{ LSD \%5 Rate } & \multicolumn{2}{|c|}{0.58} & \multicolumn{2}{|c|}{0.084} & \multicolumn{2}{|c|}{0.26} & \multicolumn{2}{|c|}{0.11} & \multicolumn{2}{|c|}{6.35} & & \\
\hline $\mathrm{LSD} \% 5 \mathrm{Se}$ & asons & & & 0. & & & & & & & & & \\
\hline
\end{tabular}


Table (5) Macro and micronutrient concentrations in rice straw and grain as affected by bio-and organic fertilizer under mineral $\mathbf{N}$ fertilization

\begin{tabular}{|c|c|c|c|c|c|c|c|c|c|c|c|c|c|c|c|c|}
\hline \multirow{2}{*}{ Treatment } & \multirow{2}{*}{$\begin{array}{l}\mathbf{N} / \\
\text { unit }\end{array}$} & \multicolumn{2}{|c|}{ N (\%) } & \multicolumn{2}{|c|}{ P (\%) } & \multicolumn{2}{|c|}{ K (\%) } & \multicolumn{2}{|c|}{$\mathrm{Fe}\left(\mathrm{mgkg}^{-1}\right)$} & \multicolumn{2}{|c|}{ Mn $\left(\mathrm{mgkg}^{-1}\right)$} & \multicolumn{2}{|c|}{ Zn $\left(\mathrm{mgkg}^{-1}\right)$} & \multicolumn{2}{|c|}{$\mathrm{Cu}\left(\mathrm{mgkg}^{-1}\right)$} & \multirow{2}{*}{$\begin{array}{l}\text { Protein } \\
(\%)\end{array}$} \\
\hline & & Straw & grain & Straw & Grain & Straw & grain & Straw & Grain & Straw & grain & Straw & Grain & Straw & Grain & \\
\hline \multirow{3}{*}{ Mineral } & 25 & 2.19 & 1.26 & 0.23 & 0.35 & 1.88 & 1.24 & 89.63 & 61.10 & 58.12 & 25.48 & 35.94 & 19.17 & 4.69 & 2.19 & 7.24 \\
\hline & 50 & 2.25 & 1.72 & 0.29 & 0.38 & 1.96 & 1.35 & 91.72 & 61.15 & 64.16 & 27.43 & 39.25 & 21.38 & 4.73 & 2.25 & 9.89 \\
\hline & 100 & 2.34 & 1.79 & 0.31 & 0.40 & 2.01 & 1.38 & 96.21 & 61.19 & 66.24 & 27.48 & 40.20 & 21.44 & 4.88 & 2.28 & 10.29 \\
\hline \multicolumn{2}{|l|}{ Mean } & 2.26 & 1.59 & 0.27 & 0.37 & 1.95 & 1.32 & 92.52 & 61.14 & 62.84 & 26.79 & 38.46 & 20.66 & 4.77 & 2.24 & 9.14 \\
\hline \multirow{3}{*}{$\begin{array}{c}\text { Bacteria } \\
\text { (NO40) }\end{array}$} & 25 & 2.24 & 1.59 & 0.25 & 0.37 & 1.93 & 1.48 & 91.18 & 62.24 & 63.14 & 25.75 & 38.66 & 21.24 & 5.26 & 2.26 & 9.14 \\
\hline & 50 & 2.36 & 1.82 & 0.32 & 0.42 & 1.99 & 1.52 & 93.34 & 62.28 & 66.47 & 27.55 & 41.21 & 22.10 & 5.33 & 2.29 & 10.46 \\
\hline & 100 & 2.29 & 1.86 & 0.35 & 0.45 & 2.03 & 1.55 & 97.38 & 62.30 & 67.19 & 27.61 & 42.16 & 22.18 & 5.42 & 2.31 & 10.69 \\
\hline \multicolumn{2}{|l|}{ Mean } & 2.29 & 1.76 & 0.31 & 0.41 & 1.98 & 1.51 & 93.97 & 62.27 & 65.60 & 26.97 & 40.68 & 21.84 & 5.34 & 2.29 & 10.10 \\
\hline \multirow{3}{*}{ Compost } & 25 & 2.28 & 1.92 & 0.28 & 0.39 & 2.01 & 1.51 & 93.10 & 62.28 & 64.29 & 26.14 & 40.00 & 21.89 & 6.14 & 2.35 & 11.04 \\
\hline & 50 & 2.34 & 2.09 & 0.34 & 0.45 & 2.08 & 1.58 & 95.20 & 62.33 & 68.09 & 27.62 & 44.10 & 22.17 & 6.21 & 2.38 & 12.02 \\
\hline & 100 & 2.41 & 2.13 & 0.38 & 0.49 & 2.12 & 1.60 & 98.06 & 62.35 & 70.12 & 27.66 & 46.58 & 22.26 & 6.29 & 2.41 & 12.25 \\
\hline \multicolumn{2}{|l|}{ Mean } & 2.34 & 2.05 & 0.33 & 0.58 & 2.07 & 1.56 & 95.45 & 62.32 & 67.50 & 27.14 & 43.56 & 22.11 & 6.21 & 2.38 & 11.77 \\
\hline \multirow{3}{*}{ Compost tea } & 25 & 2.24 & 1.88 & 0.26 & 0.35 & 1.98 & 1.50 & 92.97 & 62.32 & 63.86 & 26.13 & 39.58 & 21.81 & 6.12 & 2.33 & .81 \\
\hline & 50 & 2.29 & 2.07 & 0.33 & 0.44 & 2.05 & 1.54 & 94.88 & 62.25 & 67.84 & 27.60 & 42.56 & 22.15 & 6.17 & 2.34 & .90 \\
\hline & 100 & 2.37 & 2.09 & 0.36 & 0.47 & 2.07 & 1.59 & 96. & 62.29 & 68.91 & 27.63 & 44.29 & 22.23 & 6.19 & 2.39 & 2.02 \\
\hline \multicolumn{2}{|c|}{ Mean } & 2.30 & 2.01 & 0.31 & 0.42 & 2.03 & 1.54 & 94.88 & 62.29 & 66.87 & 27.12 & 42.14 & 22.06 & 6.16 & 2.35 & 1.57 \\
\hline \multicolumn{2}{|c|}{ LSD\%5 fertilizer } & 0.51 & 0.24 & 0.0067 & 6.96 & 0.40 & 3.43 & 2.89 & $\mathrm{~ns}$ & 1.48 & 0.57 & 0.028 & ns & $\mathrm{ns}$ & 0.57 & 1.35 \\
\hline \multicolumn{2}{|c|}{ LSD\%5 N Rate } & 0.57 & 0.49 & 0.0065 & ns & 0.98 & $\mathrm{~ns}$ & 5.72 & 3.06 & 1.70 & 0.64 & 0.032 & ns & 5.40 & 0.64 & ns \\
\hline
\end{tabular}

